\title{
Analysis of Quality Management Practice Elements Based on Performance Excellence Model
}

\author{
Yaxuan Sun ${ }^{\mathrm{a}}$ and Wei Zhu ${ }^{\mathrm{b}}$ \\ School of Management, China University of Mining and Technology (Beijing), Beijing 100083, \\ China. \\ ayaxuan_sun@163.com, b17701020338@163.com
}

Keywords: Performance Excellence Model, Quality Management Practice, Factor analysis.

\begin{abstract}
The paper summarizes domestic and foreign scholars' research on quality management practice factors by literature analysis. Based on the framework of the excellent performance model and invited quality management experts and senior leaders in company to obtain leadership support, strategic planning, customer orientation, processes management, resource allocation and continuous improvement are important elements of quality management practice.
\end{abstract}

\section{Introduction}

Quality management is a management philosophy composed of three levels which are principle, practice and technology. As the link between principle and technology, practice plays a very important role in the development of quality management, and it also has become research hotspot in quality field. Based on empirical studies by quality masters such as Crosby (1979), Deming (1982), Juran (1980), and Garvin (1984), Saraph et al. (1989) took the lead in building complete concept of Quality Management Practice by statistical analysis methods. It pointed out that quality management practice are a series of management measures and plans implemented by the organizations to improve quality, reduce costs, and increase production efficiency. Afterwards, the scholars basically followed the research ideas of Saraph et al. (1989) to refined the connotation and constituent elements of quality management practice from different perspectives. Flynn et al. (1995) subdivided quality management practice into basic practice and core practice; Powell (1995) divided quality management practice into soft and hard elements; Rahman and Bulbck (2005) divided quality management practice into soft and hard elements; Lakhal et al. (2006) divided quality management practice into management practice, basic practice and core practice; Choo et al. (2007) considered it as a frame consist of technical element and social element. Through the gradual progress of quality management practice analysis mentioned above, it can be reflected that the current scholars try to define the components of quality management practice from a multidimensional perspective but have not reached a consensus on the constituent elements of quality management practice. Therefore, according to the actual situation of China's quality management activities, this paper systematically analyzes and identifies the quality management practice elements based on the perspective of the excellent performance model.

\section{Introduction of the Performance Excellence Model}

As the evaluation standard of the Baldrige National Quality Award in the United States, the performance excellence model has become a comprehensive performance management model which has been widely recognized to improve the management level of enterprises, and has been promulgated and implemented in more than 90 countries and regions all over the world. Our country is actively introducing it and enriching it according to the national conditions. As a reference standard for enterprise self-evaluation and quality award evaluation, the performance excellence model is constantly revised according to the changes in the environment and the development of the times. The latest version is GB/T 19580-2012 Criteria for Performance Excellence, it describes the links and the logical relationship between the 7 categories in criteria (as shown in Figure 1). The "4.1 
leadership", "4.2 strategy" and "4.3 customers and the market" constitute the "leading role triangle", reflecting their driving role in the performance management system; the "4.4 resources", "4.5 process management" and "4.7 results" three parts constitute "resources, process and result triangle", indicating the use of " Resources ", through" process management "to achieve excellent results, and" 4.6 measurement, analysis and improvement "is the foundation of the performance management system, and also a link to the two triangle, can effectively promote the improvement and innovation of the enterprise, and play a vital role in improving the performance and competitiveness of the enterprise.

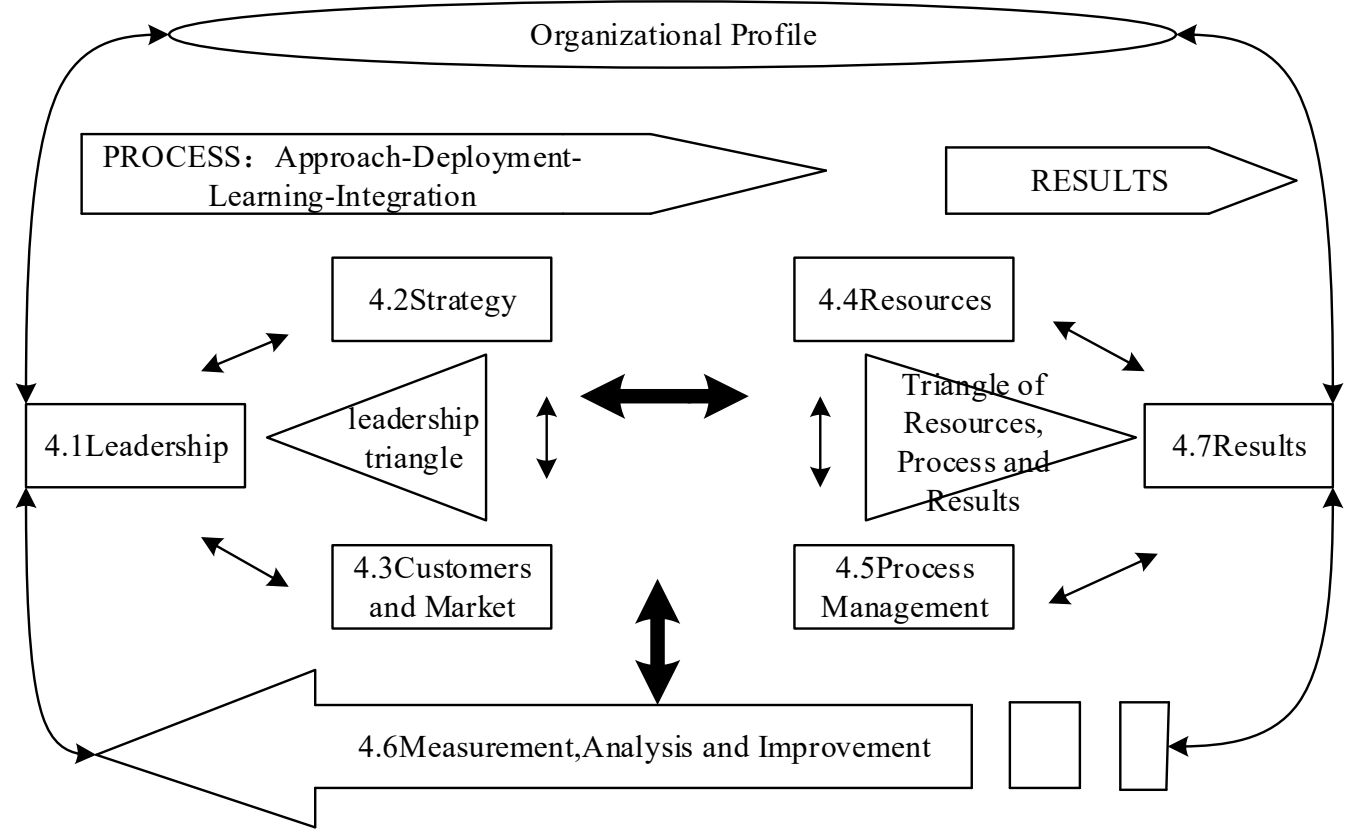

Figure 1. Framework for performance excellence evaluation

\section{Analysis of Quality Management Practice Elements}

In order to scientifically and effectively determine the quality management practice elements, this paper through literature analysis method to running through keywords like "quality management practice", "basic elements", "core elements", and "drivers" in databases such as SCI-E, SSCI, and Scopus in every possible combination, finally selected more than one hundred articles with high academic standards and discipline representativeness. And then, the relevant, practical, academic, and authoritative principles are used to read and re-screening them one by one. Quality management experts and senior leaders began discussions referred to the important research results (as shown in Table 1), on the basis of basic requirements of the excellent performance model, initially determined that quality management practice elements are composed of leadership support, strategic planning, customer orientation, process management, resource allocation, and continuous improvement. It laid the foundation for building the conceptual model based on the elements of quality management practice in the future.

\section{Conclusion}

By systematically analysis of the current research on quality management practice abroad based on the literature, this paper found that scholars basically follow the research ideas of Saraph et al. (1989) and refine the connotation and components of quality management practice from a multidimensional perspective, but no consensus has yet been reached on the elements of quality management practice. From the perspective of the performance excellence model and in light of China's actual situation, this paper believes that leadership support, strategic planning, customer orientation, process management, resource allocation, and continuous improvement are important constituent elements of quality management practice. However, there are some deficiencies in this 
paper: there is no objective analysis method and no empirical research in the process of factor selection. It is worth further research in this respect.

Table 1. Review of Quality Management Practice Elements Literature

\begin{tabular}{|c|c|}
\hline Author & Elements \\
\hline $\begin{array}{l}\text { Saraph } \\
\text { etc. }(1989)\end{array}$ & $\begin{array}{c}\text { The role of management leadership and quality policy,Role of the quality } \\
\text { department,Training,Product/Service design,Supplier quality management,Process } \\
\text { management,Quality data and reporting,Employee relations }\end{array}$ \\
\hline Powell(1995) & $\begin{array}{l}\text { Executive commitment,Adopting the philosophy,Closer to customers,Closer to } \\
\text { suppliers,Benchmarking,Training,Open organization,Emp. Empowerment,Zero defects } \\
\text { mentality,Flexible mfg.,Process improvement,Measurement }\end{array}$ \\
\hline $\begin{array}{c}\text { Flynn etc. } \\
\text { (1995) }\end{array}$ & $\begin{array}{c}\text { Top management support,Customer relationship Supplier relationship, Workforce } \\
\text { management, Work attitudes ,Product design process, Process flow } \\
\text { management ,Statistical control and feedback, External quality } \\
\text { performance,Competitive advantage }\end{array}$ \\
\hline $\begin{array}{l}\text { Samson etc. } \\
\text { (1999) }\end{array}$ & $\begin{array}{l}\text { Leadership,People management,Customer focus,Strategic planning,Information and } \\
\text { analysis,process Management }\end{array}$ \\
\hline Kaynak(2003) & $\begin{array}{l}\text { Management leadership,Training,Employee relations,Quality data and } \\
\text { reporting,Supplier quality management,Product/service design,Process } \\
\text { management,Inventory management performance,Quality performance,Financial and } \\
\text { market performance }\end{array}$ \\
\hline Nair(2007) & $\begin{array}{l}\text { Management leadership,People management,Process management,Product design and } \\
\text { management,Quality data analysis,Supplier quality management,Customer focus }\end{array}$ \\
\hline Tarí etc. (2007) & $\begin{array}{c}\text { Leadership,Quality planning,Human resource management,Supplier } \\
\text { management,Customer focus,Quality tools and techniques,Learning,Process } \\
\text { management,Continuous improvement }\end{array}$ \\
\hline $\begin{array}{c}\text { Phan etc. } \\
\text { (2011) }\end{array}$ & $\begin{array}{l}\text { Top management leadership,Formal strategic planning,Training,Small group problem } \\
\text { solving,Employee suggestions,Cross-functional product design,Housekeeping,Process } \\
\text { control,Information feedback,Customer involvement,Supplier quality involvement }\end{array}$ \\
\hline $\begin{array}{l}\text { Alonso etc. } \\
\qquad(2015)\end{array}$ & $\begin{array}{c}\text { Management commitment,Customer focus,Process management, Continuous } \\
\text { improvement }\end{array}$ \\
\hline $\begin{array}{l}\text { Antunes } \\
\text { etc. }(2017)\end{array}$ & $\begin{array}{c}\text { Leadership,Customer focus,Benchmarking,Employee } \\
\text { involvement,Development/training,Quality/product design,Measurement of the } \\
\text { results,Continuous improvement }\end{array}$ \\
\hline
\end{tabular}

\section{References}

[1]. Dean J W, Bowen D E. Management Theory and Total Quality: Improving Research and Practice through Theory Development[J]. Academy of Management Review, 1994, 19(3):392-418.

[2]. Saraph J V, Benson P G, Schroeder R G. An Instrument For Measuring The Critical Factors Of Quality[J]. Decision Sciences, 1989, 20(4):810-829.

[3]. Powell T C. Total quality management as competitive advantage: A review and empirical study[J]. Strategic Management Journal, 1995, 16(1):15-37.

[4]. Flynn B B, Schroeder R G, Sakakibara S. The Impact of Quality management practice on Performance and Competitive Advantage[J]. Decision Sciences, 1995, 26(5):659-691.

[5]. Samson D, Terziovski M. The relationship between total quality management practice and operational performance[J]. Journal of Operations Management, 1999, 17(4):393-409. 
[6]. Kaynak H. The relationship between total quality management practice and their effects on firm performance[J]. Journal of Operations Management, 2003, 21(4):405-435.

[7]. Nair A. Meta-analysis of the relationship between quality management practice and firm performance-implications for quality management theory development[J]. Journal of Operations Management, 2006, 24(6):948-975.

[8]. Taría J J, Castejón J L. The relationship between quality management practice and their effects on quality outcomes[J]. European Journal of Operational Research, 2007, 183(2):483-501.

[9]. Phan A C, Abdallah A B, Matsui Y. Quality management practice and competitive performance: Empirical evidence from Japanese manufacturing companies[J]. International Journal of Production Economics, 2011, 133(2):518-529.

[10]. Alonso-Almeida M M D, Bagur-Femenías L, Llach J. The adoption of quality management practice and their impact on business performance in small service companies: the case of Spanish travel agencies[J]. Service Business, 2015, 9(1):1-19.

[11]. Antunes M G, Quirós J T. The relationship between innovation and total quality management and the innovation effects on organizational performance[J]. International Journal of Quality \& Reliability Management, 2017, 34(4):00-00. 